\title{
Estimating annual groundwater recharge coefficient for karst aquifers of the southern Apennines (Italy)
}

\author{
V. Allocca, F. Manna, and P. De Vita \\ Dipartimento di Scienze della Terra, dell'Ambiente e delle Risorse - University of Naples "Federico II", Naples, Italy
}

Correspondence to: P. De Vita (padevita@unina.it)

Received: 24 July 2013 - Published in Hydrol. Earth Syst. Sci. Discuss.: 7 August 2013

Revised: 30 November 2013 - Accepted: 5 January 2014 - Published: 27 February 2014

\begin{abstract}
To assess the mean annual groundwater recharge of the karst aquifers in the southern Apennines (Italy), the estimation of the mean annual groundwater recharge coefficient (AGRC) was conducted by means of an integrated approach based on hydrogeological, hydrological, geomorphological, land use and soil cover analyses. Starting from the hydrological budget equation, the coefficient was conceived as the ratio between the net groundwater outflow and the precipitation minus actual evapotranspiration $(P-$ ETR) for a karst aquifer. A large part of the southern Apennines, which is covered by a meteorological network containing 40 principal karst aquifers, was studied. Using precipitation and air temperature time series gathered through monitoring stations operating in the period 1926-2012, the mean annual $P$ - ETR was estimated, and its distribution was modelled at a regional scale by considering the orographic barrier and rain shadow effects of the Apennine chain, as well as the altitudinal control. Four sample karst aquifers with available long spring discharge time series were identified for estimating the AGRC. The resulting values were correlated with other parameters that control groundwater recharge, such as the extension of outcropping karst rocks, morphological settings, land use and covering soil type. A multiple linear regression between the AGRC, lithology and the summit plateau and endorheic areas was found. This empirical model was used to assess the AGRC and mean annual groundwater recharge in other regional karst aquifers. The coefficient was calculated as ranging between 50 and $79 \%$, thus being comparable with other similar estimations carried out for karst aquifers of European and Mediterranean countries. The mean annual groundwater recharge for karst aquifers of the southern Apennines was assessed by these characterizations and
\end{abstract}

validated by a comparison with available groundwater outflow measurements.

These results represent a deeper understanding of an aspect of groundwater hydrology in karst aquifers which is fundamental for the formulation of appropriate management models of groundwater resources at a regional scale, also taking into account mitigation strategies for climate change impacts. Finally, the proposed hydrological characterizations are also supposed to be useful for the assessment of mean annual runoff over carbonate mountains, which is another important topic concerning water management in the southern Apennines.

\section{Introduction}

Karst aquifers host important groundwater resources for human and agricultural use in many areas of the world and include natural landscapes and ecosystems with great geoand biodiversities (Goldscheider, 2012). For regions in southern Italy, these aquifers are the primary source of drinking water and a strategic resource for socio-economic and environmental development (Allocca et al., 2007b); moreover their groundwater resources play a primary role in regulating the hydro-ecological regime of rivers. In this area, the public water supplies of major cities, such as Naples, which has approximately 1 million inhabitants, and many small towns and countless settlements are fed by large and small karst springs. Karst groundwater resources have also been utilized since the Roman epoch for drinking water (for example Augustan Aqueduct, dated 33-12 BC) and thermal and mineral water. These aquifers are currently important sources for several bottling plants as well. Hence, the correct estimation at 
various spatio-temporal scales of groundwater recharge processes in karst systems, corresponding to mean annual replenishment of aquifers by infiltration processes through the vadose zone (Lerner et al., 1990; Stephens, 1995; Scanlon et al., 2006; Delin et al., 2007; Healy, 2010), is a fundamental and challenging issue to be investigated for a proper management of groundwater and surface water resources. In addition, this quantitative assessment is a required approach for respecting the EU Water Framework Directive (European Commission, 2000) and taking into account effects of climatic decadal variability (De Vita et al., 2012).

A wide range of direct and indirect methods to estimate groundwater recharge processes, with a degree of approximation depending on different spatio-temporal scales, have been proposed (Scanlon et al., 2002 and references therein). Examples include lysimeter measurements, soil moisture budgets and effective infiltration coefficients, as well as water table rise, tracer and remote sensing methods. At a regional scale, to estimate the endogenous and exogenous variables controlling groundwater recharge processes, multidisciplinary analyses of hydrological time series, hydrogeological and geomorphological data have been implemented in a GIS environment (Andreo et al., 2008; Dripps and Bradbury, 2010). Moreover, conceptual and physically based models accounting for the spatial variability of parameters which controll recharge have been proposed (Hartmann et al., 2012).

For many karst aquifers around the world, the assessment of the groundwater recharge has been carried out by estimating the effective infiltration coefficient (EIC), which was defined as the ratio between the groundwater replenishment, corresponding to the net groundwater outflow, and the rainfall in a specified timescale (usually monthly or yearly) and at the aquifer scale (Drogue, 1971; Bonacci, 2001). Therefore this ratio incorporates complex processes existing in the vadose zone such as water storage, evapotranspiration, runoff and percolation to the saturated zone; it was conceived as a practical tool to assess monthly or annual groundwater recharge of an aquifer by the rainfall measurements. In karst aquifers, the EIC is controlled by several factors, among which the composition of carbonate rocks, fracturing degree, development of epikarst and deeper karst processes, slope steepness, land use and covering soil type can be basically recognized. Several estimations and applications of EIC for calcareous karst aquifers were carried out in Hungary (Kessler, 1965), Greece (Burdon, 1965; Soulios, 1984), France (Drogue, 1971) and Croatia (Vilimonovic, 1965; Bonacci, 2001), at the annual timescale, finding values ranging from 35 to $76 \%$, with a mean value around $51 \%$. Finally, for other non-European countries, a value of $27 \%$ was assessed for the dolomitic basin of Tennesee (Sodeman and Tysinger, 1965). In Italy, Boni et al. (1982) reported an annual EIC value of $70 \%$ for some karst aquifers in the central Apennines.
The aim of this study was to assess the average annual groundwater recharge of the main karst aquifers of the southern Apennines (Italy) by estimating the annual groundwater recharge coefficient (AGRC), which was set similarly to the EIC (Drogue, 1971; Bonacci, 2001) and adapted to be more suitable for a regional-scale application. This assessment was conceived as a key aspect of groundwater hydrology in karst aquifers of the southern Apennines which would provide an effective tool to estimate annual groundwater recharge. To achieve this objective, an integrated approach based on the hydrological budget applied to precipitation, evapotranspiration and spring discharge time series, as well as geomorphological settings, land use and type of soil cover analyses was carried out. The applied methods were based on all the available data and were set up to solve the temporal and spatial discontinuities of hydrological time series, specifically the lack of significant measurements for both springs discharge and precipitation in the high altitude ranges.

The paper is organized as follows: after a description of the issue and a review of the literature in Sect. 1, the hydrogeological characteristics of the karst aquifers of the southern Apennines are described in Sect. 2, which are followed by the data and methods, results, discussion and concluding remarks in Sects. 3, 4 and 5, respectively.

\section{Hydrogeology of karst aquifers and climatic characteristics of the southern Apennines}

The southern Apennines consist of a series of mountain ranges in which karst aquifers form the major massifs (Fig. 1). In this area, karst aquifers cover approximately $8560 \mathrm{~km}^{2}$ (Fig. 1) and consist mainly of Triassic-Liassic dolomites, Jurassic limestones and Paleogene marly limestones of the Mesozoic carbonate platform series, which were tectonically deformed and piled up in the fold-andthrust belt Apennine structure during the Miocene orogenic phases (Patacca and Scandone, 2007). The karst aquifers of the southern Apennines in several cases are characterized by large plateau and endorheic zones on the top and exhibit an average inclination of structurally controlled slopes of approximately $30-35^{\circ}$, related to the morphological evolution of original fault line scarps (Brancaccio et al., 1978; Bull, 2007). Moreover, given their proximity to volcanic centers (Fig. 1), these aquifers were singularly covered by variable thicknesses of ash-fall pyroclastic deposits (De Vita et al., 2006, 2013) that erupted during the Quaternary, whose presence influences the epikarst development (Celico et al., 2010).

Regional hydrogeological studies carried out in the southern Apennines analysed groundwater circulation in main karst aquifers by understanding geological and structural constraints that control groundwater paths and assessing large groundwater bodies outflowing chiefly in basal springs, with mean annual discharges varying from 0.1 to $5.5 \mathrm{~m}^{3} \mathrm{~s}^{-1}$. 


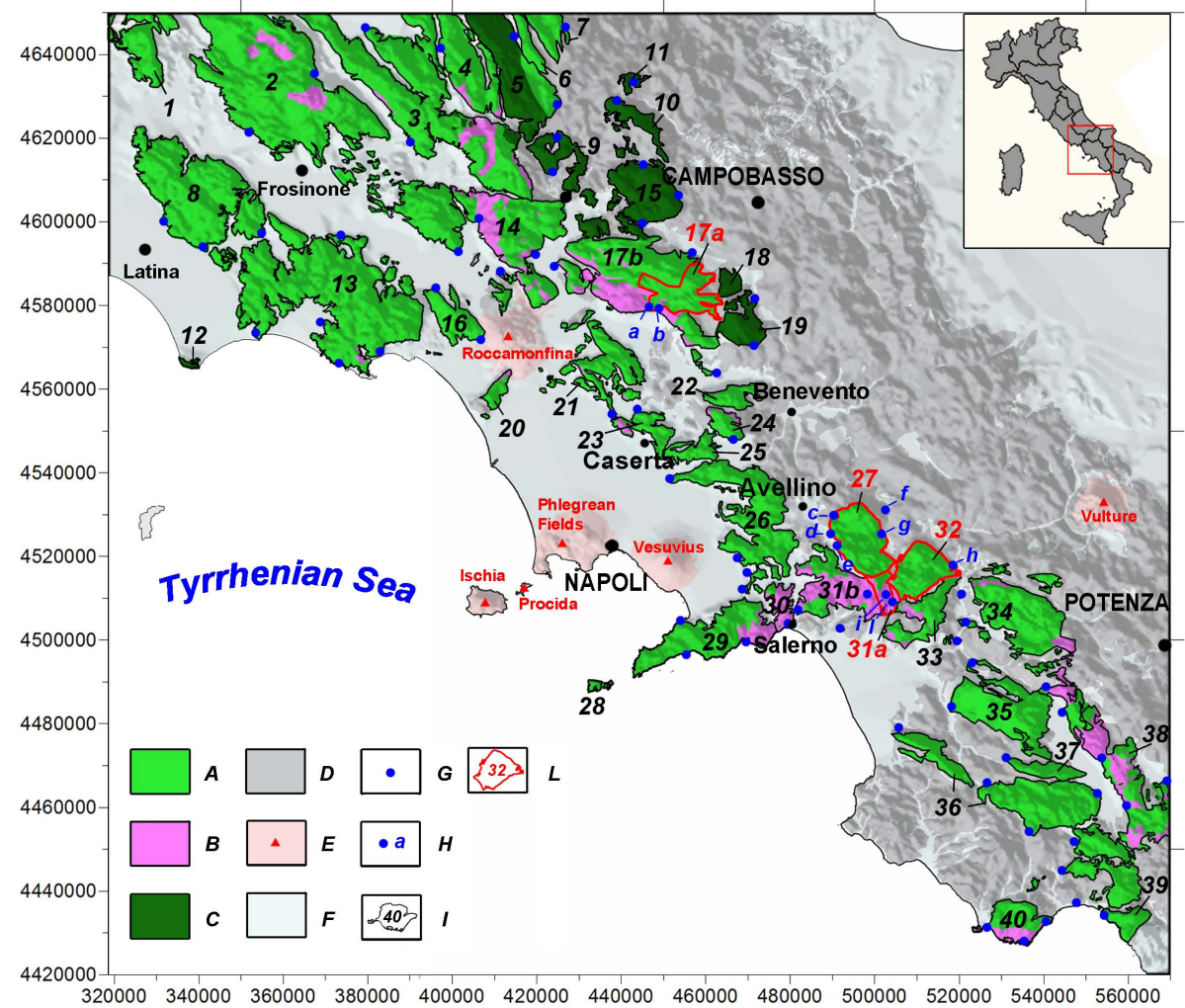

Fig. 1. Map of the karst aquifers of the southern Apennines. Key to symbols: (A) limestone and dolomitic limestone units of the carbonate platform series (Jurassic-Paleogene); (B) dolomitic units of the carbonate platform series (Trias-Liassic); (C) calcareous-marly units of the outer basin series (Trias-Paleogene); (D) pre-, syn- and late- orogenic molasses and terrigenous units (Cretaceous-Pliocene); (E) volcanic centers (Pliocene-Quaternary); (F) alluvial and epiclastic units (Quaternary); (G) main basal springs of karst aquifers; (H) basal karst springs considered in the hydrological budget (a and b: Maretto and Torano; c: Salza Irpina; d and e: Serino; f: Baiardo; g: Cassano Irpino; h: Sanità; i: Avella; 1: Ausino-Ausinetto); (I) hydrogeological boundary and identification number of the karst aquifers; (L) hydrogeological boundary and identification number of the karst aquifers considered for the hydrological budget.

The hydrogeological behaviour of these aquifers (Celico, 1988; Allocca et al., 2007a) is in accordance with principal conceptual models proposed for karst aquifers (White, 1969, 2002; Mangin, 1975; Kiraly, 1975, 2002; Drogue, 1992; Bonacci, 1993; Klimchouk, 2000; Civita et al., 1992; Jeannin, 1998; Goldscheider and Drew, 2007; Fiorillo, 2011a). Due to the fold-and-thrust belt structure of the Apennine, karst aquifers are tectonically juxtaposed to hydrostratigraphic units of lower permeability belonging to preand syn-orogenic basinal and flysch series. Therefore, the groundwater circulation of karst aquifers is basically controlled by the geometry of stratigraphic or tectonic contacts with these units of lower permeability, being generally oriented toward the lowest point of the hydrogeological boundary (Celico, 1983; Allocca et al., 2007a), where basal springs are located (Fig. 1). In these zones, the groundwater circulation can also feed alluvial and detrital aquifers in lateral contact with karst aquifers. Inversely, in other specific conditions, groundwater circulation of alluvial and detrital aquifers can feed that of karst aquifers. Other minor stratigraphic or tectonic factors subdivide the basal groundwater circulation inside karst aquifers. These include faults with low-permeability damage and core zones or intervals in the carbonate series with marly or argillaceous composition that compartmentalize the aquifers in basin-in-series systems (Celico, 1988; Celico et al., 2006). Though karst systems (ISSKA, 2012) belonging to the same aquifer can be fed by variable contributing areas (Ravbar et al., 2011), in the cases of the southern Apennines the whole recharge area of a karst aquifer can be considered constant and corresponding to the outcrop of karst rocks, owing to distinct structural and stratigraphic constraints with juxtaposing hydrogeological units of lower permeability. An exception is given for those very limited cases of allogenic recharge coming from adjoining alluvial aquifers or concentrated-secondary infiltration of runoff formed on the surrounding or overlying nonkarst terrains.

A subordinate perched groundwater flow, related to epikarst and/or superimposed aquifers, also occurs in the surficial part, where stratigraphic and structural factors or the presence of small karst conduits can generate highaltitude seasonal and ephemeral springs characterized by 
mean annual discharges generally lower than $0.01 \mathrm{~m}^{3} \mathrm{~s}^{-1}$. The groundwater recharge of karst aquifers occurs chiefly by autogenic recharge due to diffuse-direct net infiltration through the epikarst. For several karst aquifers of the southern Apennines, the mean annual groundwater flow was assessed mostly on the basis of short-duration and discontinuous time series (frequently less than three years) or few nonsystematic instantaneous measurements of spring discharges.

The climatic characteristics of the southern Apennines and their temporal variability strongly control the recharge processes in karst aquifers, and both are influenced by the North Atlantic Oscillation (De Vita et al., 2012). The climate of this sector of Italy varies from Mediterranean type (Csa) in the coastal sector to Mediterranean mild climate $(\mathrm{CSb})$ in the inland areas (Geiger, 1954). The spatial distribution of mean annual precipitation is mainly influenced by the orographic effect (Henderson-Sellers and Robinson, 1986) of the Apennine mountain ranges on humid air masses moving eastward from the Tyrrhenian Sea. According to the location of the Apennine chain, higher orographic precipitation occurs in the western sector, with maximum values up to 1700 $2000 \mathrm{~mm}$ along the Apennine ridge itself. Eastward of the Apennine ridge, lower precipitations down to $700-900 \mathrm{~mm}$ are recorded because of the rain shadow effect.

\section{Data and methods}

This study was carried out in a large sector of the southern Apennines covering approximately $19339 \mathrm{~km}^{2}$, corresponding to the regional hydrological network of the National Hydrographic and Tidal Service, Department of Naples. The basic hydrogeological characteristics that control groundwater recharge in karst aquifers over this territory (Fig. 1) were assessed: extension of the recharge areas, outcropping lithology, morphological settings (slope angle distribution and summit plateau/endorheic areas), land use and type of soil cover. Precipitation and air temperature time series recorded by all monitoring stations functioning over the same territory in the period 1926-2012 were also collected and analysed. Moreover, four sample karst aquifers were identified to estimate the AGRC on the basis of the availability of significant spring discharge time series and representativeness of the lithological and morphological settings (Fig. 1): the Matese (a), Accellica (a), Terminio and Cervialto karst aquifers. Although not numerous, the examined sample aquifers are the only ones for which long time series of spring discharges are available in the southern Apennines.

\subsection{Estimation of annual groundwater recharge coefficient}

The EIC (Drogue, 1971; Bonacci, 2001) being essentially the ratio between the net groundwater outflow ( $Q_{\text {OUT }}$ ) and rainfall $(P)$ for an analysed karst aquifer and a fixed timescale (monthly or annual),

$\mathrm{EIC}=\frac{Q_{\mathrm{OUT}}}{P}$

was conceived incorporating the evapotranspiration loss. For this reason the EIC was not considered applicable to a regional scale such as the southern Apennines, where differences in the spatial distributions of rainfall and air temperature lead to different evapotranspiration rates over karst aquifers (Fiorillo, 2011b), and not exportable even in the cases of lithological and morphological similarities. Therefore the EIC structure was modified for taking into account the role of the evapotranspiration, in a form of a new coefficient calculated at the annual timescale, named annual groundwater recharge coefficient (AGRC).

The AGRC was estimated for each of the four sample karst aquifers, by applying the hydrological budget equation to the whole recharge area, equivalent to the outcropping extension of the aquifer, and considering average values for the period 1926-2012:

$P-\mathrm{ETR}=R+\left(Q_{\mathrm{s}}+Q_{\mathrm{t}}\right)+\left(U_{\mathrm{o}}-U_{\mathrm{i}}\right) \pm \Delta W_{\mathrm{r}}$,

where $P$ is the mean annual precipitation, ETR is the mean annual actual evapotranspiration, $R$ is the mean annual runoff, $Q_{\mathrm{s}}$ is the mean annual spring discharge, $Q_{\mathrm{t}}$ is the mean annual tapped discharge, $U_{\mathrm{o}}$ is the mean annual groundwater outflow through adjoining aquifers, $U_{\mathrm{i}}$ is the mean annual groundwater inflow from adjoining aquifers and other allogenic recharge, and $\pm \Delta W_{\mathrm{r}}$ is the interannual variation of groundwater reserves.

Because interannual variation of groundwater reserves $\left( \pm \Delta W_{\mathrm{r}}\right)$ is approximately negligible in the long-term timescale, as it results by the complexly cyclical decadal variability around the mean value found (De Vita et al., 2012) for the Cervialto, Terminio and Matese karst aquifers (No. 32, 27 and 17 in Fig. 1), Eq. (2) can be simplified as follows:

$P-\mathrm{ETR}-R=\left(Q_{\mathrm{s}}+Q_{\mathrm{t}}\right)+\left(U_{\mathrm{o}}-U_{\mathrm{i}}\right)$.

The mean AGRC was estimated for each karst aquifer as the ratio between the mean annual net groundwater outflow $\left[Q_{\text {oUT }}=\left(Q_{\mathrm{s}}+Q_{\mathrm{t}}\right)+\left(U_{\mathrm{o}}-U_{\mathrm{i}}\right)\right]$ and the mean annual precipitation minus actual evapotranspiration $(P-$ ETR $)$, where both were related to the whole recharge area:

$\mathrm{AGRC}=\frac{\left(Q_{\mathrm{s}}+Q_{\mathrm{t}}\right)+\left(U_{\mathrm{o}}-U_{\mathrm{i}}\right)}{P-\mathrm{ETR}}$.

Due to the general hydrogeological settings along the boundaries, mean annual groundwater outflows $\left(U_{\mathrm{o}}\right)$ through juxtaposed alluvial and detrital aquifers were considered significant for the Matese (a), Terminio and Accellica (a) cases only; instead, groundwater inflows $\left(U_{\mathrm{i}}\right)$ were assessed as negligible or non-existent. Groundwater outflows $\left(U_{\mathrm{o}}\right)$ were 
estimated by the application of Darcy's law (Darcy, 1856) to measurements of hydraulic transmissivity, length of the draining section and hydraulic gradient, known from preceding hydrogeological studies (Celico, 1983; Allocca et al., 2007a). In detail, groundwater outflows $\left(U_{\mathrm{o}}\right)$ were assessed as a very limited fraction of the mean annual net groundwater outflow ( $Q_{\text {OUT }}$ ), corresponding to 3, 2 and $7 \%$, respectively for the three sample aquifers.

The annual EIC (AEIC) and AGRC are linked by a simple relationship, which can be obtained by combining Eqs. (1) and (4):

$\mathrm{AEIC}=\mathrm{AGRC} \times \frac{P-\mathrm{ETR}}{P}$.

Furthermore, due the peculiar morphological setting of karst aquifers, summit plateau areas (slope angle $\leq 5^{\circ}$ ) and endorheic watersheds, in which the infiltration value reaches the maximum value (AGRC $=100 \%$ ), were identified and measured. The annual effective infiltration coefficient for the slope part $\left(\mathrm{AGRC}_{\mathrm{S}}\right)$, in non-endorheic conditions and with a slope angle greater than $5^{\circ}$, was therefore calculated by the following formula:

$\mathrm{AGRC}_{\mathrm{S}}=\left[\frac{\left(\mathrm{AGRC} \times A_{\mathrm{T}}\right)-\left(1 \times A_{\mathrm{E}}\right)}{A_{\mathrm{T}}-A_{\mathrm{E}}}\right] \times 100$,

where $A_{\mathrm{T}}$ is the total area of the karst aquifer $\left(\mathrm{km}^{2}\right)$, and $A_{\mathrm{E}}$ is the cumulative extension of summit plateau areas and/or endorheic watersheds $\left(\mathrm{km}^{2}\right)$.

This estimation was considered useful for a comprehensive understanding of the hydrological role of karst aquifers, and thus also for taking into account a general assessment of runoff formation along karst slopes (Horvat and Rubinic, 2006) by estimating the annual runoff coefficient (ARC), which is the complementary part of the AGRC:

$\mathrm{ARC}=100-\mathrm{AGRC}_{\mathrm{S}}$.

The ARC can be compared to runoff coefficients, which are usually calculated as the ratio between surface runoff and rainfall, by considering the ratio $(P-\mathrm{ETR}) / P$ homologously as for Eq. (5).

\subsection{Hydrological data}

The mean annual precipitation data (387 rain gauge stations) and air temperatures (228 monitoring stations) were gathered from the annals of the National Hydrographic and Tidal Service in the period 1926-1999 (www.isprambiente.gov.it) and the Regional Civil Protection Agency databases (www. protezionecivile.gov.it) for the remaining interval from 2000 to 2012. During the entire period, the number of rain gauge stations varied from a total of 175 in 1926 to a minimum of 52 during 1943-1944, up to a maximum of 225 from 1972 to 1984 to a current value of 171 . The number of the air temperature stations began with 19 in 1926, increased to 90 in
1975, and then oscillated around this number up to now. Nevertheless, more than $50 \%$ of the monitoring stations worked for longer than $30 \mathrm{yr}$ and approximately $10 \%$ of the stations ran for more than $70 \mathrm{yr}$. Another issue of this monitoring network was the prevailing distribution of stations in the lowermiddle altitude ranges (0-600 m a.s.1.), which is a limiting factor in assessing hydrological data at the highest altitude ranges.

Time series were analysed to reconstruct regional distribution models of mean annual precipitation $(P)$, air temperature $(T)$ and precipitation minus actual evapotranspiration $(P-\mathrm{ETR})$, thereby accounting for variations due to orographic control of mountain ranges (Roe, 2005; Houze, 2012) and altitude (Vuglinski, 1972; Brunsdon et al., 2001) in a GIS environment. For the $P$ - ETR data set, a linear correlation analysis between mean annual values and altitude was carried out identifying homogeneous precipitation zones by distinctive relationships between $P-$ ETR and altitude as well as according to geographical location of rain gauge stations respect to the principal morphological divide of the Apennine chain. For each precipitation zone, an empirical model was calculated by means of a linear regression weighted by the number of years of functioning of each station (Carroll and Ruppert, 1988).

To estimate the mean annual $P$-ETR over the period 1926-2012, the actual evapotranspiration was calculated for each rain gauge station by Turc's formula (Turc, 1954), which was based on annual runoff, air temperature and precipitation of 254 drainage basins distributed in different climates and continents. The reliability of this empirical model, was also confirmed by studies in the Mediterranean (Santoro, 1970) and European areas (Parajka and Szolgay, 1998; Horvat and Rubinic, 2006) as well as through mean annual hydrological budgets carried out for principal aquifers of southern Italy (Boni et al., 1982; Celico, 1983; Allocca et al., 2007a):

$$
\mathrm{ETR}_{j}=\frac{P_{j}}{\sqrt{0.9+\left(\frac{P_{j}}{300+25 \cdot T_{j}+0.05 \cdot T_{j}^{3}}\right)^{2}}},
$$

where $\mathrm{ETR}_{j}$ is the mean annual actual evapotranspiration $(\mathrm{mm})$ for the $j$ rain gauge station; $P_{j}$ is the mean annual precipitation (mm) for the $j$ rain gauge station; and $T_{j}$ is the mean annual air temperature $\left({ }^{\circ} \mathrm{C}\right)$ for the $j$ air temperaturerain gauge station.

The actual evapotranspiration was also calculated for those rain gauge stations not provided with an air temperature sensor. In these cases, the mean annual air temperature was estimated by the empirical linear regression model with the altitude. Moreover, in order to assess the regional variability of the mean annual actual evapotranspiration, the ratio $(P-$ ETR $) / P$ was calculated for each rain gauge station.

By the daily discharge time series of basal springs of the sample karst aquifers, the mean annual spring discharges 

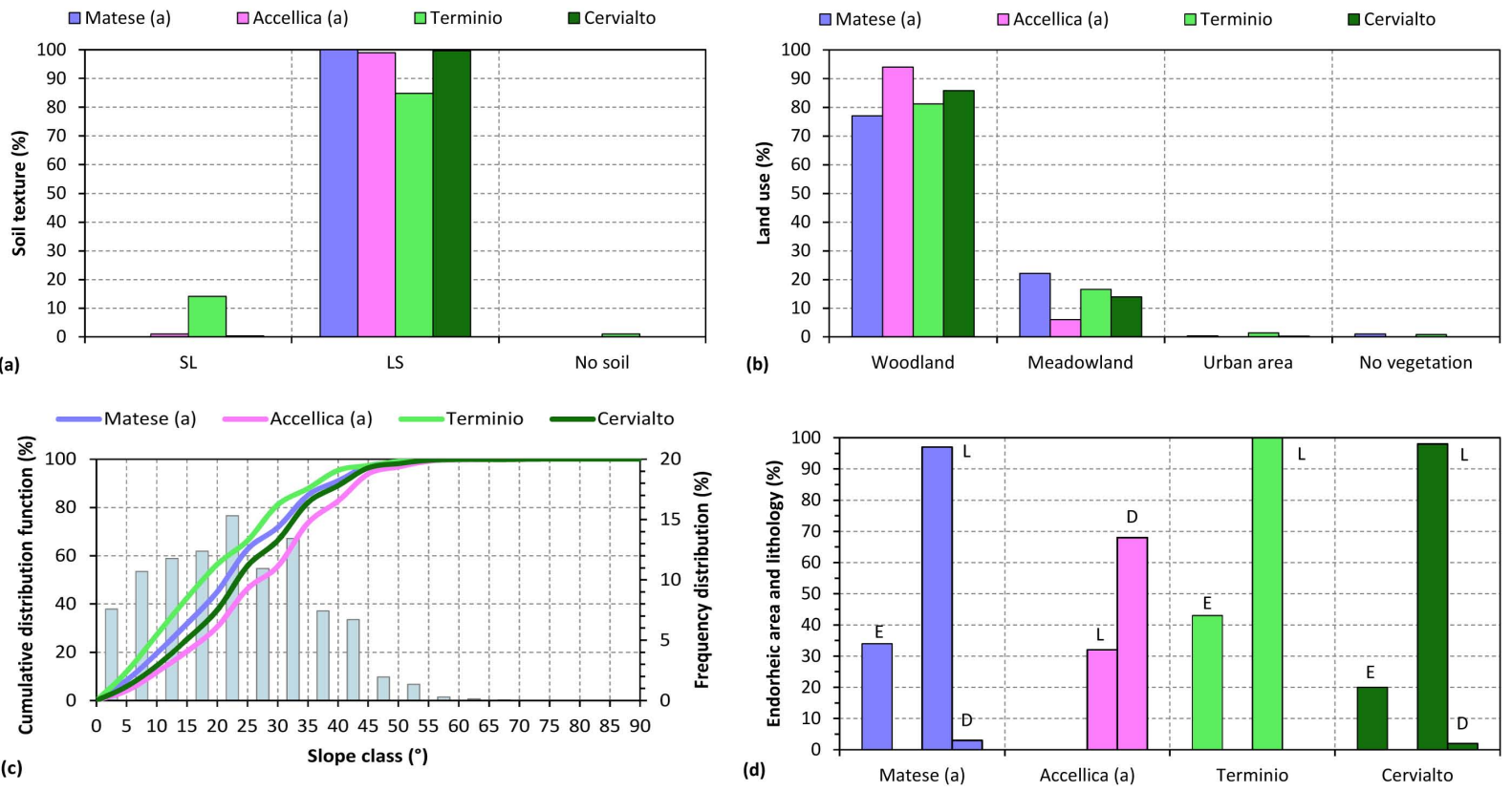

Fig. 2. Soil texture type, land use and geomorphological characteristics of the four sample karst aquifers. (a) Soil texture frequency (SL Sandy Loam, LS Loamy Sand. (b) Land use frequency. (c) Slope of karst aquifers frequency. (d) Summit endorheic and plateau areas frequency $(E)$ and lithology $(\mathrm{L}=$ limestone; $\mathrm{D}=$ dolomite $)$.

were calculated (Fig. 1). Specifically for the Matese (a) karst aquifer, the Maretto and Torano springs were considered (recording period from 1967-2000 and 1957-2000, respectively). For the Terminio aquifer, the Cassano Irpino (recording period 1965-2010), Serino (recording period 18872010) and Baiardo and Salza Irpina springs (recording period 1970-2000) were analysed. For the Cervialto aquifer, the Sanità spring, which represents the sole outflow of the entire karst aquifer and a unique case for the duration of its time series (recording period 1921-2012), was considered (De Vita et al., 2012). For the Accellica (a) karst aquifer, the Avella and Ausino-Ausinetto springs (recording period 1967-1989) were considered.

\subsection{Aquifer lithology, covering soil type, land use and geomorphological data}

On the basis of preceding hydrogeological studies carried out for singular aquifers and synthesized in reviews of regional relevance (Celico, 1983; Allocca et al., 2009), 40 principal karst aquifers were identified (Fig. 1). The outcropping lithology of the karst aquifers were assessed by analysing hydrogeological maps of southern Italy, 1:250000 scale (Allocca et al., 2007a).

To analyse the types of soil covering such aquifers, the Land System Map of the Campania Region, 1:250000 scale (www.risorsa.info), and the Ecopedological Map of Italy, $1: 250000$ scale (www.pcn.minambiente.it), were consulted. In addition, data from Corine Land Cover 2006 (www.eea.europa.eu) were collected to analyse land use. A national $20 \mathrm{~m}$ grid spacing digital elevation model (http: //www.sinanet.isprambiente.it) was analysed to examine the morphological features of the karst aquifers, giving special attention to slope angle and extension of the endorheic catchments. The above-mentioned spatial data were implemented in a geographical information system, which allowed for the analysis of the spatial frequency of such parameters for each examined karst aquifer.

\section{Results}

\subsection{Extension and lithology of the recharge areas}

Extension and lithology of the recharge areas of the 40 karst aquifers were assessed by analysing regional hydrogeological maps (Allocca et al., 2007a). Specifically, the four sample karst aquifers were shown to be representative, both by their significant extensions and their outcropping lithology (Fig. 2): Matese (a) $\left(120 \mathrm{~km}^{2} ; 97 \%\right.$ limestone and $3 \%$ dolomite); Accellica (a) $\left(35 \mathrm{~km}^{2} ; 68 \%\right.$ dolomite and $32 \%$ limestone); Terminio $\left(167 \mathrm{~km}^{2} ; 100 \%\right.$ limestone $)$ and Cervialto $\left(129 \mathrm{~km}^{2} ; 98 \%\right.$ limestone and $2 \%$ dolomite).

\subsection{Soil type, land use and geomorphological features}

The analysis of soil types covering karst aquifers identified the loamy sand type (coded as LS in Figs. 2a and 3a) as the prevailing one with a percentage greater than $90 \%$ for three of the four karst aquifers considered, which is consistent with 

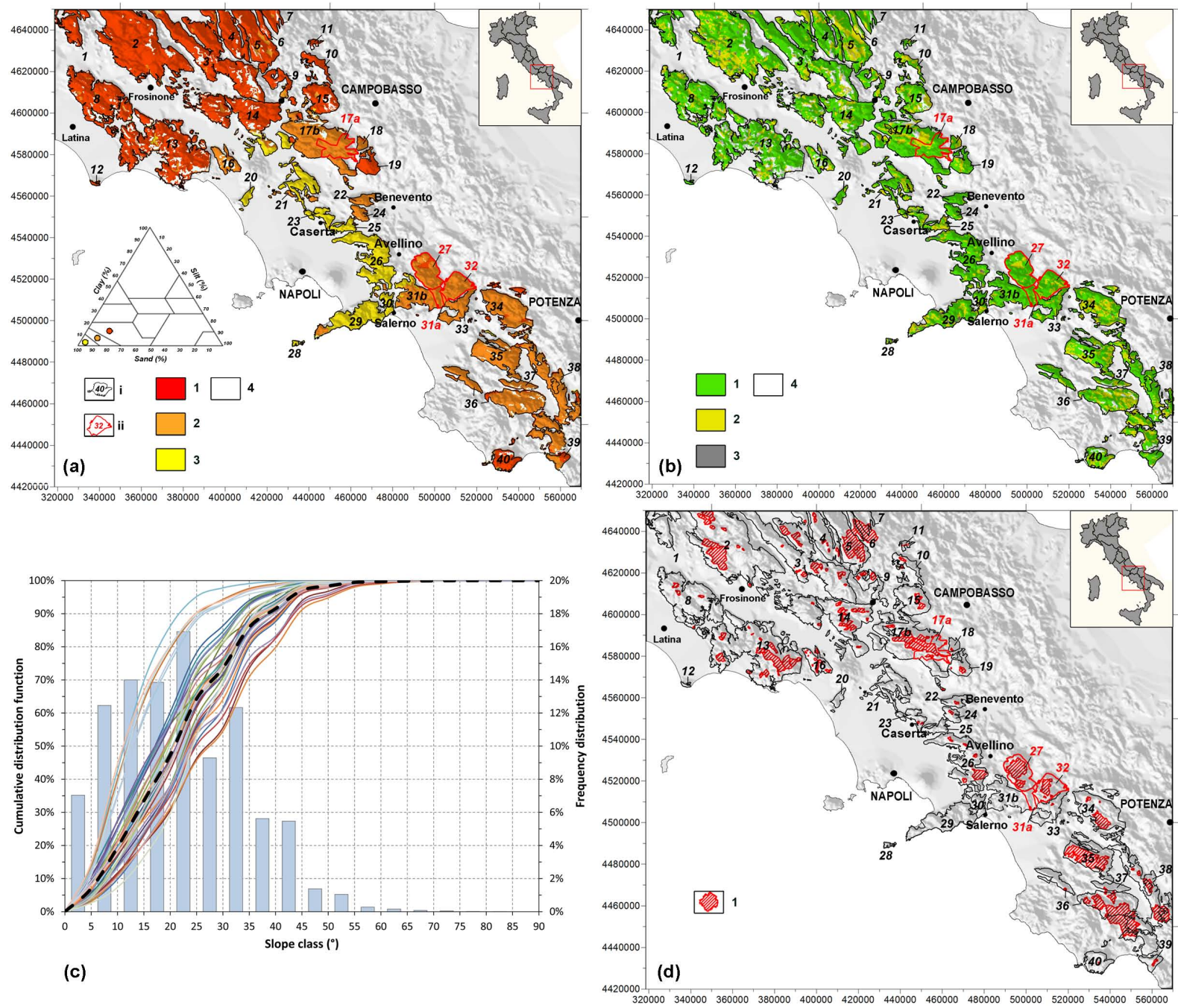

Fig. 3. (a) Soil texture map. Common symbols: (i) hydrogeological boundary and identification number of the karst aquifers; (ii) hydrogeological boundary and identification number of the sample karst aquifers. Key to symbols: (1) sandy loam soil; (2) loamy sand soil; (3) sandy soil; (4) area with no soil. (b) Land use map. Key to symbols: (1) woodland; (2) meadowland; (3) urban area; (4) no vegetation area. (c) Frequency analysis of the slope angle distribution for the karst aquifers. Key to symbol: (coloured line) Cumulative distribution of single karst aquifer; (dashed black line) Mean cumulative distribution; (histogram) Mean frequency distribution. (d) Summit plateau areas and endorheic watersheds map. Key to symbol: (1) limits of endorheic watershed.

Naclerio et al. (2008, 2009). A fraction of a coarser soil type, $14 \%$ of sandy loam soils (coded as SL in Fig. 3a), was identified for the Terminio karst aquifer according to other studies carried out at a detailed scale (Allocca et al., 2008; Fiorillo, $2011 \mathrm{~b}$ ) and the proximity to the Somma-Vesuvius volcano, which led to the deposition both of greater thicknesses of ash-fall pyroclastic deposits (De Vita et al., 2006) and coarser grain sizes.

Land use varied among four principal typologies: woodland, meadowland, areas without vegetation cover and urban areas. Specifically, the woodland and meadowland classes were the dominant ones in the four sample karst aquifers, extending for approximately 85 and $14 \%$ of the total area, respectively (Figs. $2 \mathrm{~b}$ and $3 \mathrm{~b}$ ).
The sample karst aquifers were found to have extensions of summit plateau areas and endorheic zones (Figs. 2d and 3d) varying from $43 \%$ in the case of Terminio to $0 \%$ for Accellica (a), with intermediate values of approximately 35 and $20 \%$ for Matese (a) and Cervialto, respectively. Moreover, the cumulative distributions of slope angle were found to be similar across the sample and other aquifers (Figs. $2 \mathrm{c}$ and $3 \mathrm{c}$ ), showing a similar median value of $25^{\circ}$.

Considering the 40 karst aquifers identified at a regional scale (Fig. 1), the soil type was notably homogeneous (Fig. 3a) with a prevalence of sand in each category. Average land use values of $69 \%$ for woodland, $25 \%$ for meadowland, $5 \%$ for areas without vegetation and $1 \%$ for urban areas were estimated (Fig. 3b). The morphological settings 

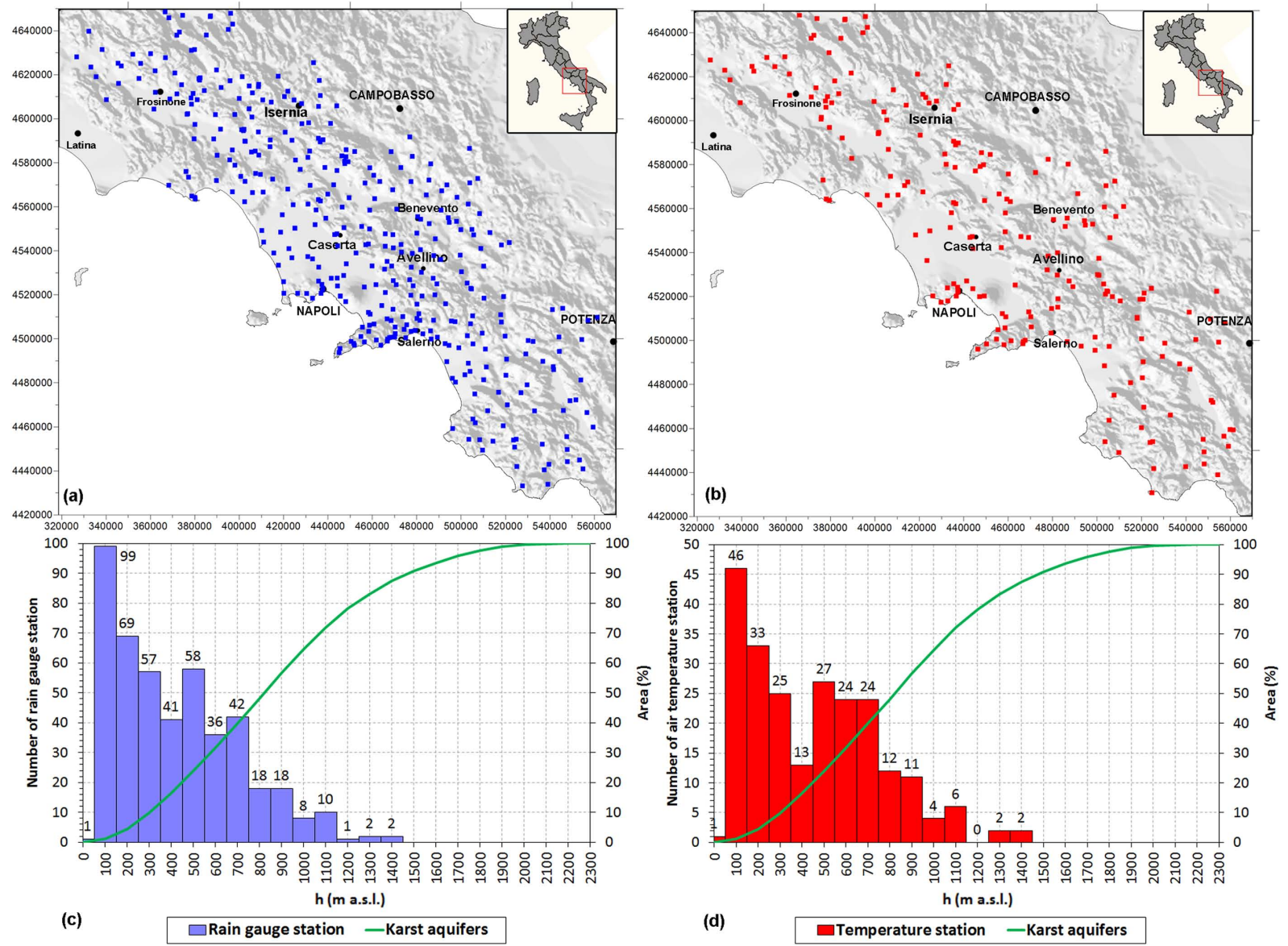

Fig. 4. Spatial distributions of rain gauge stations (a) and air temperature stations (b). Comparisons between the hypsometric curve of the 40 karst aquifers in the study area and the altitudinal distribution of rain gauge stations (c) and air temperature stations (d).

of all karst aquifers showed very similar cumulative distributions of slope angles, with a median of $25^{\circ}$ and a modal value ranging within $20-25^{\circ}$. In contrast, the most frequent higher value slope angle class was $30-35^{\circ}$, according to the typical morphological setting, due to the erosional evolution of faultline scarps in carbonate mountains of the southern Apennines (Brancaccio et al., 1978; Bull, 2007). Significant differences were observed in the distribution and extent of the summit plateau and endorheic areas (Fig. 3d and Table 2) according to the different structural settings of the karst aquifers. More extended summit plateau and endorheic watersheds were detected in the northern and in the southern parts of the study area. In particular, more than $40 \%$ of the total area of the Terminio and Alburni karst aquifers (Fig. 3d and Table 2) were characterized by summit plateau area and endorheic watersheds, and hence by a complete infiltration of the $P-$ ETR amount.

\subsection{Annual precipitation minus actual evapotranspiration $(P-$ ETR $)$}

Despite the apparent homogeneous distribution of rain gauges and air temperature stations over the territory (Fig. 4a and $b$ ), the assessment of the spatial distribution of these stations revealed an inhomogeneous scattering with altitude, with a dominant presence in the lower-middle ranges (Fig. 4c and d). This scarcity of a monitoring network at higher altitude ranges was recognized as a principal issue to overcome in order to assess the groundwater recharge of karst aquifers, which have a mountainous morphology extending up to the highest altitudes. In fact, the statistical comparison between the altitude of the monitoring stations and the karst aquifers showed that $50 \%$ of these areas lie at altitudes between 800 and $2280 \mathrm{~m}$ a.s.l., where only $10 \%$ of rain gauge and air temperature stations are located (Fig. $4 \mathrm{c}$ and d).

At the regional scale, despite of the mean annual precipitation, the spatial variability of the mean annual air temperature was found to be correlated with the altitude by a unique and statistically robust linear regression model (Fig. $5 \mathrm{~d}): T\left({ }^{\circ} \mathrm{C}\right)=-0.0064 \times h(\mathrm{~m}$ a.s.1. $)+16.5\left(r^{2}=0.733\right.$; 

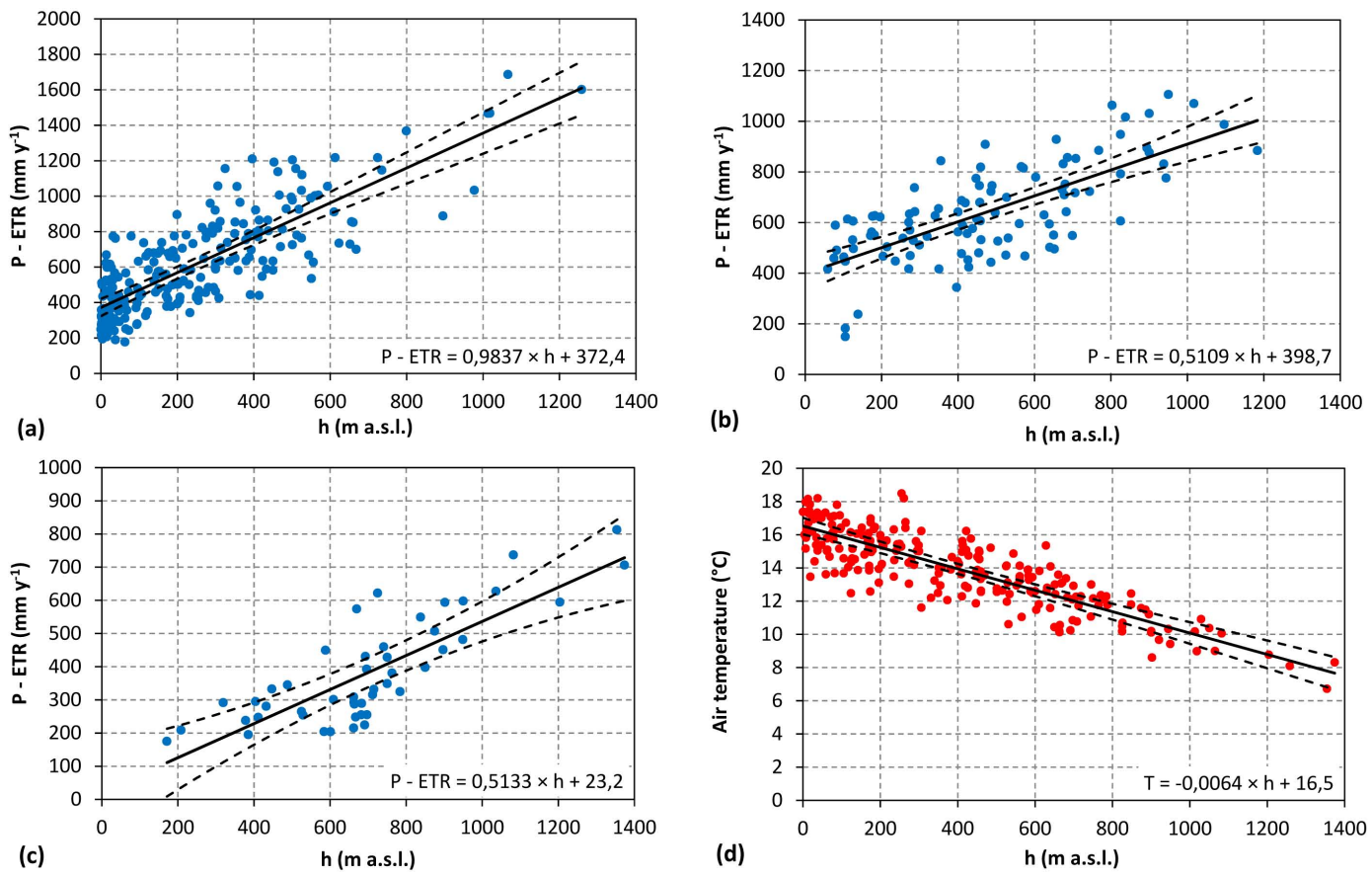

Fig. 5. Linear correlations and confidence limits (95\%) between mean annual $P$ - ETR and altitude for upwind zone (a), first downwind zone (b) and second downwind zone (c). The correlation between mean annual air temperature and altitude is also shown (d).

Prob. F-Fisher $<0.1 \%$ ). This empirical model was applied to estimate the mean annual air temperature for rain gauge stations not provided with air temperature sensors, thus permitting to calculate mean annual ETR for all the 387 rain gauge stations.

To estimate groundwater recharge at a regional scale, a distributed model of the mean annual $P$ - ETR was reconstructed by considering the spatial variability due to both orographic and altitudinal controls. By analysing the correlation of $P$-ETR data with the altitudes of the rain gauge stations, three homogeneous precipitation zones were found, according to the orographic barrier effect (Vuglinski, 1972; Brunsdon et al., 2001) of the Apennine chain. An upwind zone, extending from the coastline to the principal Apennine morphological divide, and two downwind zones eastward of the same divide were identified (Figs. 5 and 6), which resulted from a rain shadowing effect (Roe, 2005). For each zone, a specific linear regression model, weighted by the years of functioning of each rain gauge station, was identified between $P-$ ETR and altitude (Fig. 5a-c). These models showed that the $P$-ETR values progressively increase with altitude, even considering three different empirical laws across the Apennine chain, which were always statistically significant if considering the $95 \%$ confidence inter$\operatorname{val}\left(r_{\min }^{2}=0.510\right.$ and Prob. F-Fisher $\left.<0.1 \%\right)$.

On the basis of such findings, a general distributed model of $P$ - ETR was reconstructed by integrating the three precipitation zones in a GIS layer (Fig. 6a and b). For the upwind pluviometric zone, the recorded values of mean $P$-ETR ranged between 373 and $1606 \mathrm{~mm}$, but varied from 200 to $1010 \mathrm{~mm}$ for the two downwind zones.

The ratio $(P-$ ETR $) / P$ was analysed for all the available rain gauge stations, finding a significant variability from 0.11 to 0.82 , a mean value of $0.48 \pm 0.21$ (95\% confidence interval) and a linear correlation with the altitude $(P-$ ETR $) / P($ ad. $)=0.0002 \times h($ m a.s.l. $)+0.398\left(r^{2}=\right.$ 0.396; Prob. F-Fisher $<0.1 \%)$. This result, also represented as a map (Fig. 6c), testified to the strong differences of the mean annual ETR at the regional scale, which are controlled by spatial variability of both mean annual air temperature and precipitation (Eq. 8).

\subsection{AGRC and $\mathrm{AGRC}_{\mathrm{S}}$ estimations}

From the calculation of the variables forming Eqs. (4) and (6), the AGRC and AGRCS were estimated for the four sample karst aquifers (Table 1), which also took into account the uncertainties due to the linear regression models (95\% confidence limits) of $P-$ ETR and altitude (Fig. 7). Due to the structure of Eq. (4) and the different uncertainty of its variables ( $Q_{\text {OUT }}$ and $P-\mathrm{ETR}$ ), the AGRC uncertainty is chiefly controlled by that of the $P$ - ETR and altitude regression models. Considering the results related to the mean value of the regression models, similar values of the AGRC were found for the Terminio, Cervialto and Matese (a) karst aquifers, corresponding to 79,71 and $69 \%$, respectively, whereas a value of $50 \%$ was calculated for the Accellica (a) karst aquifer. This difference appeared to be mainly 
Table 1. AGRC and mean $\mathrm{AGRC}_{\mathrm{S}}$ estimation for the investigated sample karst aquifers. Values are related to the mean value of the $P-$ ETR linear regression models with altitude.

\begin{tabular}{llrrrrrrr}
\hline ID & Karst aquifer & $\begin{array}{r}\text { Area } \\
\left(\mathrm{km}^{2}\right)\end{array}$ & $\begin{array}{c}\text { Summit } \\
\text { plateau/ } \\
\text { endorheic } \\
\text { area }(\%)\end{array}$ & $\begin{array}{r}V_{\text {outflow }} \\
\left(10^{6} \mathrm{~m}^{3} \mathrm{yr}^{-1}\right)\end{array}$ & $\begin{array}{r}V_{\text {inflow }} \\
\left(10^{6} \mathrm{~m}^{3} \mathrm{yr}^{-1}\right)\end{array}$ & $\begin{array}{c}\text { AGRC } \\
(\%)\end{array}$ & $\begin{array}{c}\mathrm{AGRC}_{\mathrm{S}} \\
(\%)\end{array}$ & $\begin{array}{c}\text { ARC } \\
(\%)\end{array}$ \\
\hline 17a & Matese (a) & 120 & 34 & & & & & \\
27 & Terminio & 167 & 43 & 169.7 & 138.1 & 69 & 52 & 48 \\
31a & Accellica (a) & 35 & 0 & 18.3 & 36.3 & 79 & 64 & 36 \\
32 & Cervialto & 129 & 20 & 126.1 & 178.4 & 71 & 50 & 50 \\
\hline
\end{tabular}

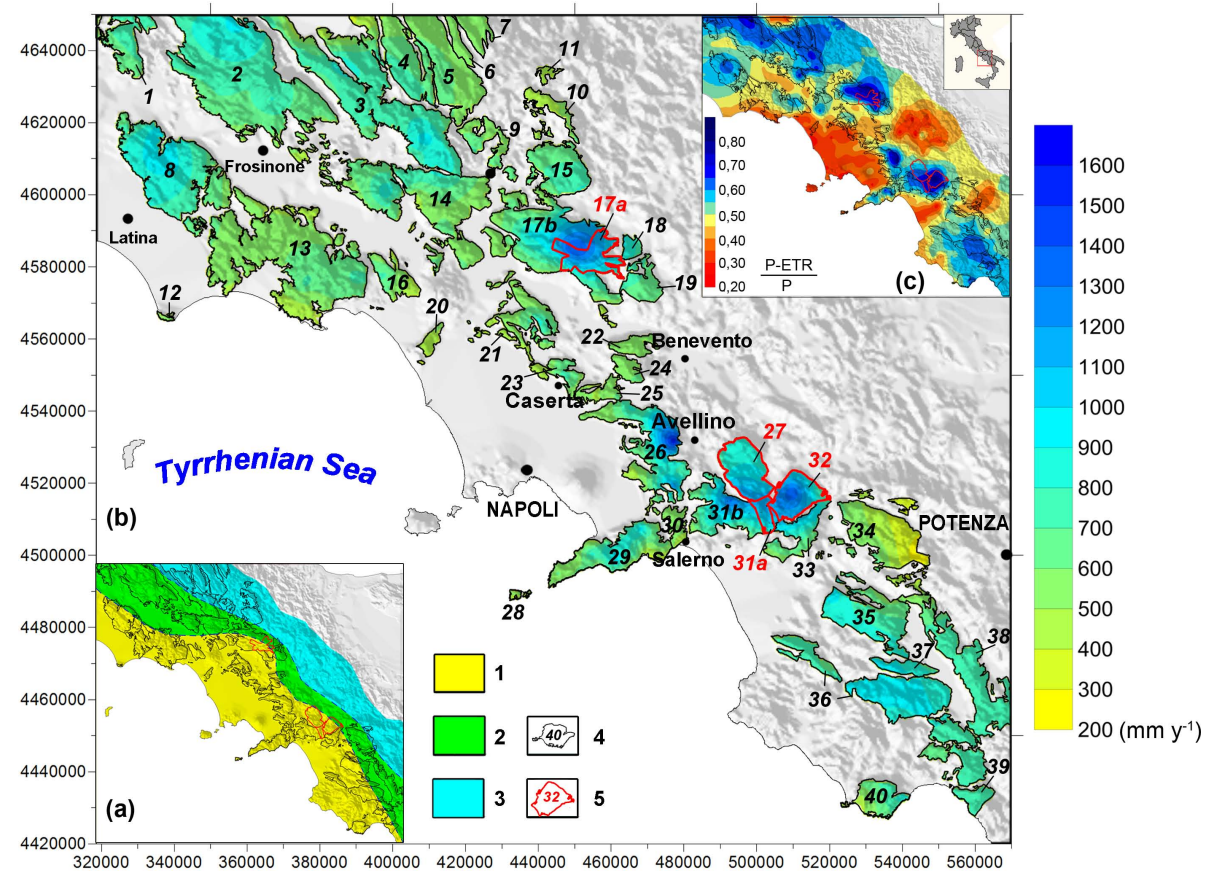

Fig. 6. Homogeneous precipitation zones (a), distributed model of mean annual $P-$ ETR $(\mathbf{b})$ and of mean annual $(P-$ ETR $) / P$ ratio $(\mathbf{c})$. Key to symbol: (1) upwind zone; (2) first downwind zone; (3) second downwind zone; (4) hydrogeological boundaries and identification number of the karst aquifers; (5) hydrogeological boundaries and identification number of the karst aquifers considered for the hydrological budget.

correlated to the different lithology, which is prevailingly dolomitic, and the lack of summit plateau and endorheic areas for the latter case. Corresponding $\mathrm{AGRC}_{\mathrm{S}}$ and $\mathrm{ARC}$ values (Table 1 and Fig. 7) were estimated as ranging from 50 to $64 \%$ and from 50 to $36 \%$, respectively.

\subsection{Regional assessment of the groundwater recharge}

To generalize the results obtained for the four sample karst aquifers at a regional scale, a bivariate correlation analysis was carried out between the AGRC and limestone area, summit plateau and endorheic area, woodland area, loamy sand soil type area and mean slope angle. A significant correlation was found for limestone $\left(r^{2}=0.901\right.$;
Prob. F-Fisher $=1.3 \%$ ) and summit plateau endorheic areas $\left(r^{2}=0.931\right.$; Prob. F-Fisher $\left.=0.14 \%\right)$ only. Instead, the correlation analyses revealed a scarce statistical significance (Prob. F-Fisher $\geq 15 \%$ ) of the last three parameters on the AGRC variability. Consequently, a multiple linear regression to empirically correlate the mean AGRC to the basic controlling variables, namely limestone area $(\mathrm{L} \%)$ and summit plateau and endorheic area (E\%), was found:

AGRC $=47.99+0.08 \mathrm{~L}+0.51 \mathrm{E}$,

which was statistically significant $\left(r^{2}=0.968\right.$; Prob. FFisher $=3.0 \%$; standard errors of 5.92, 0.06 and 0.07 for the intercept, first and second coefficient, respectively). 

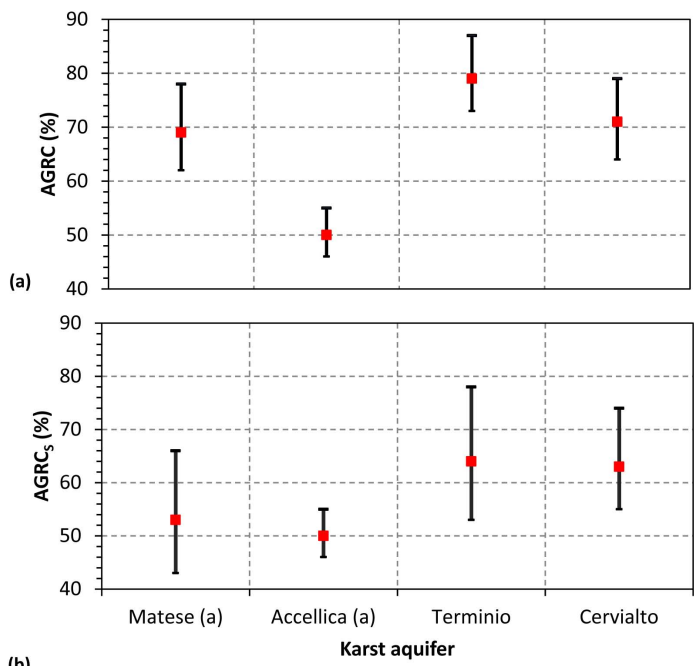

(b)

Fig. 7. $A G R C$ (a) and $A_{G R C}$ (b) estimations for the four sample karst aquifers obtained considering uncertainties of the annual $P-$ ETR and air temperature regression models $(95 \%$ confidence limits).

The preceding equation confirms the insight that the plateau and endorheic area is a factor affecting the mean AGRC more strongly than lithology (outcrop of karst rocks).

The AGRC and AGRCs values for the 40 regional karst aquifers by applying the empirical Eqs. (9) and (6) (Table 2) were assessed. The minimum estimated AGRC value was calculated for the Circeo karst aquifer (48\%); the maximum value was found for the Terminio karst aquifer (78\%), with a residual of $1 \%$ respect directly calculated to that (Table 1 ) and a mean global value of $59 \%$.

The estimation of the AGRC and $P-$ ETR values (Fig. 6) for each karst aquifer allowed for the assessment of the respective mean annual groundwater recharge (Table 2), which was assessed at the regional scale (Fig. 8). To validate this empirical estimation, the recharge values calculated by Eq. (9) for the four sample karst aquifers were compared with the outflow discharges. The resulting residuals between the predicted recharge and measured outflow was considered to be negligible, ranging between 0 and $10 \%$ (Table 2 and Fig. 9), and thus supporting the reliability of the empirical estimations. Moreover, the correlation between the estimated mean annual groundwater recharge and the measured groundwater outflow, appraised for 18 of the 40 karst aquifers by non-systematic spring discharges measurements carried out during the 1970s and 1980s (Celico, 1983; Allocca et al., 2007a), showed consistent results (Fig. 9) both in terms of angular coefficient and statistical significance (Prob. F-Fisher $<0.1 \%$ ).

\section{Discussion and conclusions}

The estimation of the AGRC is proposed as a practical tool to assess annual groundwater recharge in karst aquifers of the southern Apennines and forecast the effects of annual to decadal climatic variability. The applied methods were oriented to account for the lack of temporal and spatial hydrological time series, namely the availability of significant spring discharge measurements and precipitation records in the high altitude ranges. Consequently, results are based on all existing and available hydrological data.

A contribution to reconstruct a regional distributed model of $P$ - ETR that also accounts for orographic barrier and altitude controls of the Apennine chain is provided by identifying three homogeneous zones in which distinctive empirical laws exist relatively to altitude. This approach is proposed as a simpler and more direct method for distributively assessing the amount of $P-\mathrm{ETR}$, potentially involved in groundwater recharge, which is not based on geostatistical analyses (Goovaerts, 2000; Marquínez et al., 2003) but on the recognition of the orographic barrier and altitude controls (Vuglinski, 1972; Brunsdon et al., 2001).

The estimations of the AGRC for four sample karst aquifers varied from 50 to $79 \%$ with a mean value of $67 \%$. These results are similar to those estimations carried out previously by Celico (1988) and Allocca et al. (2007a), who heuristically assessed AGRC values up to $90 \%$ for karst aquifers of the southern Apennines, taking their typical summit plateau and endorheic morphologies into account.

No other comparisons are possible due to the new structure of the proposed coefficient. Nonetheless, by means of Eq. (5) and considering a mean annual value of the $(P-$ ETR $) / P$ ratio approximately equal to 0.7 for the four sample karst aquifers, the AGRC values are quite comparable to those of annual EIC (AEIC), which were determined in the European and peri-Mediterranean areas (Burdon, 1965; Vilimonovic, 1965; Drogue, 1971; Bonacci, 2001) and previously as described in the Introduction section.

The four sample karst aquifers are the only cases for which spring discharges were measured for a long duration and the AGRC is more accurately estimable. Because of the accurate assessment of mean annual groundwater outflow and inflow volumes for the four sample karst aquifers, the calculated values of the AGRC represent a reliable approach to model groundwater recharge for these aquifers.

Owing to the similarity of the other karst aquifers, an empirical estimate of the mean AGRC was also proposed for those aquifers, hence attempting a regionalization of the groundwater recharge modelling. Using a correlation analysis of other factors recognisable as affecting groundwater recharge in sample karst aquifers, such as lithology, morphological settings, land use and covering soil type, an empirical relationship between AGRC, summit plateau and/or endorheic areas and lithology was found. In spite of the limited number of data, this empirical relationship is statistically 
Table 2. Data and estimations of $\mathrm{AGRC}, \mathrm{AGRC}_{\mathrm{S}}, \mathrm{ARC}$ and mean annual groundwater recharge for karst aquifers of the study area. In the last column, the mean annual groundwater outflow, estimated for some of the karst aquifers by other hydrogeological studies (Celico, 1983; Allocca et al., 2007) are reported; values estimated in this study for the four sample karst aquifers (ID 17a, 27, 31a and 32) are reported.

\begin{tabular}{|c|c|c|c|c|c|c|c|c|c|c|}
\hline ID & Karst aquifer & $\begin{array}{r}\text { Area } \\
\left(\mathrm{km}^{2}\right)\end{array}$ & $\begin{array}{r}\text { Mean } \\
\text { annual } \\
P-\text { ETR } \\
(\mathrm{mm})\end{array}$ & $\begin{array}{r}\text { Limestone } \\
\text { area } \\
(\%)\end{array}$ & $\begin{array}{r}\text { Summit } \\
\text { plateau and } \\
\text { endorheic } \\
\text { area } \\
(\%)\end{array}$ & $\begin{array}{c}\text { AGRC } \\
(\%)\end{array}$ & $\begin{array}{c}\mathrm{AGRC}_{\mathrm{S}} \\
(\%)\end{array}$ & $\begin{array}{c}\text { ARC } \\
(\%)\end{array}$ & $\begin{array}{r}\text { Mean } \\
\text { annual } \\
\text { groundwater } \\
\text { recharge } \\
\left(10^{6} \mathrm{~m}^{3} \mathrm{yr}^{-1}\right)\end{array}$ & $\begin{array}{r}\text { Mean } \\
\text { annual } \\
\text { groundwater } \\
\text { outflow } \\
\left(10^{6} \mathrm{~m}^{3} \mathrm{yr}^{-1}\right)\end{array}$ \\
\hline 1 & Cerella & 137 & 738 & 100 & 0 & 56 & 56 & 44 & 57.0 & - \\
\hline 2 & Simbruini & 1075 & 896 & 94 & 12 & 62 & 57 & 43 & 596.7 & - \\
\hline 3 & Cornacchia & 723 & 940 & 90 & 7 & 59 & 56 & 44 & 402.6 & - \\
\hline 4 & Marsicano & 204 & 845 & 94 & 5 & 58 & 56 & 44 & 100.8 & - \\
\hline 5 & Genzana & 277 & 814 & 10 & 34 & 66 & 49 & 51 & 149.6 & - \\
\hline 6 & Rotella & 40 & 800 & 100 & 40 & 77 & 62 & 38 & 24.6 & - \\
\hline 7 & Porrara & 63 & 753 & 100 & 25 & 69 & 59 & 41 & 32.9 & - \\
\hline 8 & Lepini & 483 & 990 & 100 & 2 & 57 & 57 & 43 & 274.3 & 400.5 \\
\hline 9 & Colli Campanari & 88 & 702 & 0 & 12 & 54 & 48 & 52 & 33.4 & - \\
\hline 10 & Capraro & 70 & 586 & 0 & 5 & 51 & 48 & 52 & 20.7 & - \\
\hline 11 & Campo & 16 & 692 & 0 & 13 & 55 & 48 & 52 & 6.1 & - \\
\hline 12 & Circeo & 6 & 548 & 0 & 0 & 48 & 48 & 52 & 1.7 & - \\
\hline 13 & Ausoni & 822 & 835 & 99 & 15 & 64 & 58 & 42 & 438.2 & 507.7 \\
\hline 14 & Venafro & 362 & 796 & 74 & 11 & 60 & 55 & 45 & 172.4 & 269.3 \\
\hline 15 & Totila & 183 & 535 & 0 & 8 & 52 & 48 & 52 & 51.2 & - \\
\hline 16 & Maio & 93 & 706 & 98 & 12 & 63 & 58 & 42 & 41.0 & - \\
\hline $17 \mathrm{a}$ & Matese (a) & 120 & 1151 & 97 & 34 & 74 & 60 & 40 & 101.8 & 95.2 \\
\hline $17 \mathrm{~b}$ & Matese (b) & 480 & 1151 & 65 & 15 & 61 & 55 & 45 & 338.1 & 375.0 \\
\hline 18 & Tre Confini & 28 & 830 & 0 & 4 & 50 & 48 & 52 & 11.6 & - \\
\hline 19 & Moschiaturo & 85 & 887 & 0 & 7 & 51 & 48 & 52 & 38.6 & - \\
\hline 20 & Massico & 29 & 700 & 89 & 0 & 55 & 55 & 45 & 11.4 & - \\
\hline 21 & Maggiore & 157 & 719 & 99 & 0 & 56 & 56 & 44 & 63.5 & 56.7 \\
\hline 22 & Camposauro & 50 & 935 & 99 & 4 & 58 & 56 & 44 & 27.4 & - \\
\hline 23 & Tifatini & 80 & 646 & 90 & 2 & 56 & 56 & 44 & 29.2 & 25.2 \\
\hline 24 & Taburno & 43 & 1212 & 81 & 4 & 57 & 55 & 45 & 29.8 & - \\
\hline 25 & Durazzano & 52 & 775 & 100 & 0 & 56 & 56 & 44 & 22.7 & - \\
\hline 26 & Avella & 334 & 983 & 100 & 9 & 61 & 57 & 43 & 201.2 & - \\
\hline 27 & Terminio & 167 & 1277 & 100 & 43 & 78 & 62 & 38 & 167.4 & 169.7 \\
\hline 28 & Capri & 9 & 565 & 93 & 0 & 56 & 56 & 44 & 2.7 & - \\
\hline 29 & Lattari & 244 & 868 & 75 & 0 & 54 & 54 & 46 & 115.2 & - \\
\hline 30 & Salerno & 46 & 734 & 13 & 0 & 49 & 49 & 51 & 16.6 & 21.1 \\
\hline $31 \mathrm{a}$ & Accellica (a) & 35 & 1055 & 32 & 0 & 51 & 51 & 49 & 18.7 & 18.3 \\
\hline $31 b$ & Accellica (b) & 171 & 1055 & 33 & 0 & 51 & 51 & 49 & 91.6 & 107.6 \\
\hline 32 & Cervialto & 129 & 1383 & 98 & 20 & 67 & 58 & 42 & 119.0 & 126.1 \\
\hline 33 & Polveracchio & 117 & 1257 & 81 & 0 & 55 & 55 & 45 & 80.9 & 103.1 \\
\hline 34 & Marzano & 292 & 776 & 97 & 13 & 63 & 57 & 43 & 142.0 & - \\
\hline 35 & Alburni & 254 & 1162 & 99 & 42 & 78 & 62 & 38 & 230.5 & 233.4 \\
\hline 36 & Cervati & 318 & 1225 & 81 & 13 & 62 & 56 & 44 & 241.0 & 220.8 \\
\hline 37 & Motola & 52 & 1179 & 100 & 4 & 59 & 57 & 43 & 35.7 & 37.8 \\
\hline 38 & Maddalena & 307 & 859 & 59 & 21 & 64 & 54 & 46 & 168.8 & 97.8 \\
\hline 39 & Forcella & 217 & 965 & 86 & 5 & 58 & 56 & 44 & 121.4 & - \\
\hline 40 & Bulgheria & 100 & 785 & 68 & 1 & 54 & 54 & 46 & 42.5 & 42.5 \\
\hline
\end{tabular}

significant, allowing for the regionalization of the groundwater recharge for karst aquifers of the southern Apennines. A few other studies have tried to regionalize karst aquifer characteristics with topographic and climatic descriptors (Andreo et al., 2008) and by defining signatures derived from hydrodynamic and hydrochemical observations (Hartmann et al., 2013).

The proposed approach highlights another complementary aspect related to the estimation of annual runoff along slope areas, which is particularly relevant for the management of surficial water resources. The calculated mean ARC values 


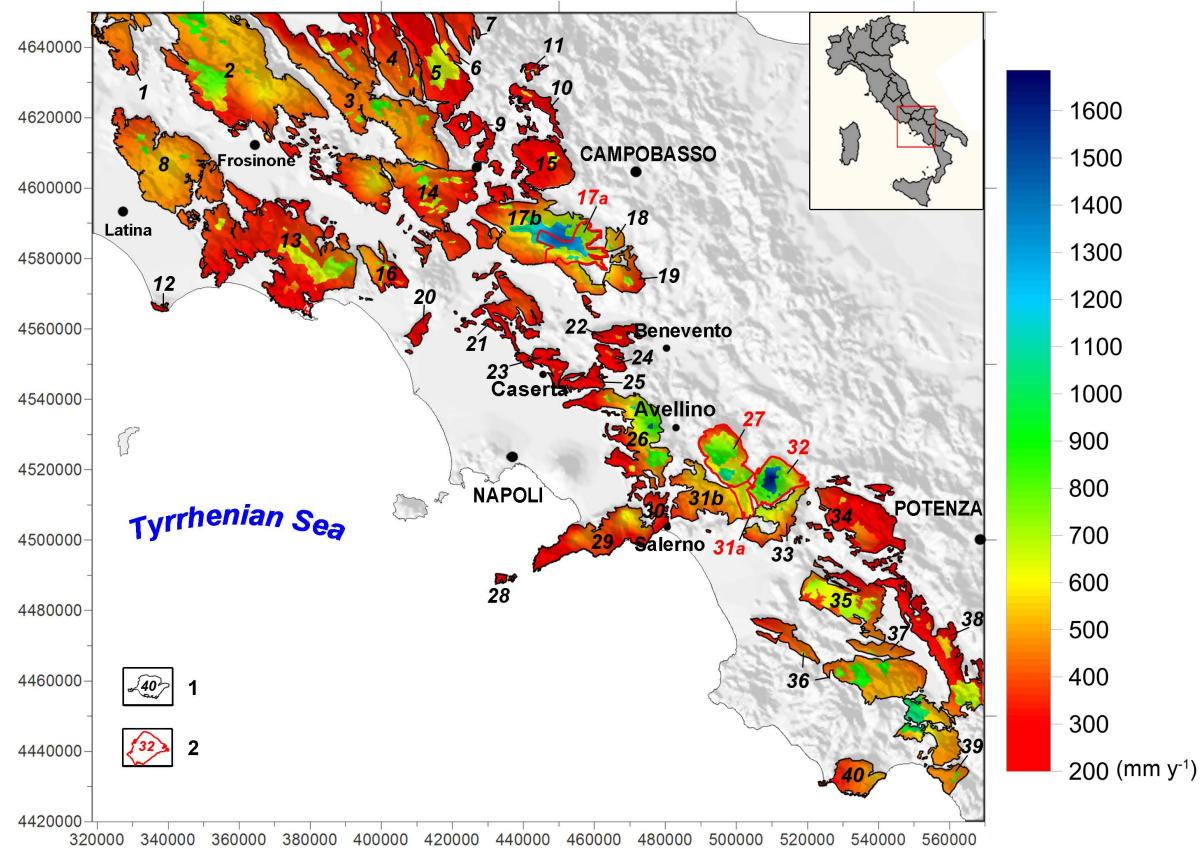

Fig. 8. Distributed model of the mean annual groundwater recharge for karst aquifers of the southern Apennines. Key to symbol: (1) hydrogeological boundaries and identification number of the karst aquifers; (2) hydrogeological boundaries and identification number of the karst aquifers considered for the hydrological budget.

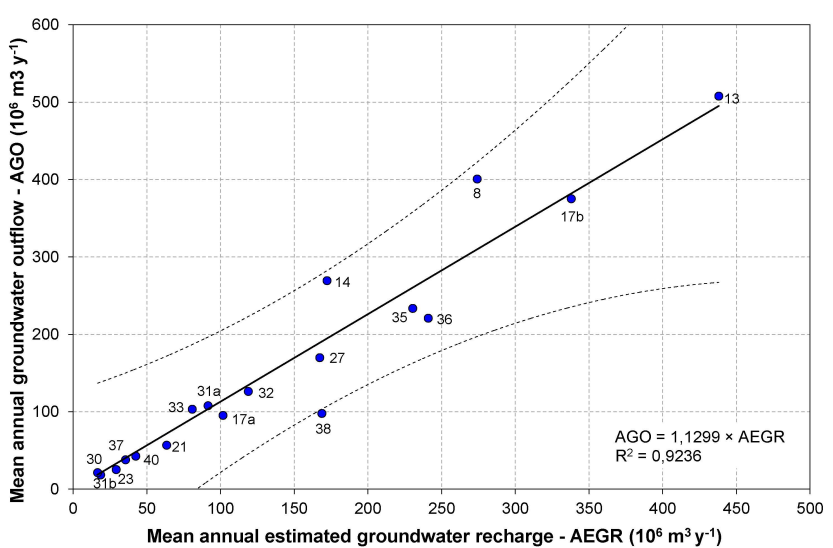

Fig. 9. Correlation between mean annual groundwater outflow (AGO) assessed by non-systematic spring discharges measurements and mean annual estimated groundwater recharge (AEGR). The numbers correspond to the aquifers' ID. The $95 \%$ confidence bands are also shown.

varying from 36 to $50 \%$ can be approximately compared with those determined for Dinaric karst aquifers (Horvat and Rubinic, 2006) and some river basins of southern continental Italy (Del Giudice et al., 2013).

The methodology is presented as a reliable and practical approach for modelling the groundwater recharge of karst aquifers at regional and mean annual scales in the case of a large territory with discontinuous and absent hydrological monitoring. It can be conceived as a deeper understanding of groundwater hydrology in karst aquifers and a first step to overcoming the lack of spring discharges and piezometric levels' time series. The application of this method would thus permit the design of appropriate management models for groundwater and surface resources of karst aquifers as well as the setting up of accurate strategies to mitigate the effects of climate change. This achievement would allow the balancing of environmental needs and societal impacts of water uses, as required by the EU Water Framework Directive (European Commission, 2000).

Acknowledgements. We thank Gerardo Ventafridda of the Apulian Aqueduct (www.aqp.it), who provided discharge data for the Cassano Irpino and the Sanità karst springs, and the Department of Civil Protection of the Campania region (www.regione.campania.it), which kindly provided the rainfall and temperature data. We are also grateful to Pierre-Yves Jeannin, Andrew J. Long and two other anonymous referees who provided constructive reviews of the manuscript.

Edited by: N. Romano 


\section{References}

Allocca, V., Celico, F., Celico, P., De Vita, P., Fabbrocino, S., Mattia, S., Monacelli, G., Musilli, I., Piscopo, V., Scalise, A. R., Summa, G., and Tranfaglia, G.: Illustrative Notes of the Hydrogeological Map of Southern Italy, Istituto Poligrafico e Zecca dello Stato, Rome, 1-211, 2007a.

Allocca, V., De Vita, P., Fabbrocino, S., and Celico, P.: The karst aquifers of the southern Apennines (Italy): a strategic groundwater resource, Mem. Ist. It. Speleo, II, XIX, 65-72, $2007 \mathrm{~b}$.

Allocca, V., Celico, F., Petrella, E., Marzullo, G., and Naclerio, G.: The role of land use and environmental factors on microbial pollution of mountainous limestone aquifers, Environ. Geol., 55, 277-283, 2008.

Allocca, V., Celico, F., Celico, P., De Vita, P., Fabbrocino, S., Mattia, C., Monacelli, G., Musilli, I., Piscopo, V., Scalise, A. R., Summa, G., and Tranfaglia, G.: La carta idrogeologica dell'Italia meridionale. Metodi ed analisi territoriali per l'identificazione e la caratterizzazione dei corpi idrici sotterranei (Direttiva 2000/60/CE), L'Acqua, 4, 21-32, 2009.

Andreo, B., Vías, J., Durán, J. J., Jiménez, P., López-Geta, J. A., and Carrasco, F.: Methodology for groundwater recharge assessment in carbonate aquifers: application to pilot sites in southern Spain, Hydrogeol. J., 16, 911-925, 2008.

Bonacci, O.: Karst spring hydrographs as indicators of karst aquifers, Hydrolog. Sci. J., 38, 51-62, 1993.

Bonacci, O.: Montly and annual effective infiltration coefficients in Dinaric karst: example of the Gradole karst spring catchment, Hydrological Sciences - Journal des Sciences Hydrologiques, 46, 287-299, 2001.

Boni, C., Bono, P., and Capelli, G.: Valutazione quantitativa dell'infiltrazione efficace in un bacino dell'Italia centrale: confronto con analoghi bacini rappresentativi di diversa litologia, Geologia Applicata e Idrogeologia, 17, 437-452, 1982.

Brancaccio, L., Cinque, A., and Sgrosso, I.: L'analisi dei versanti di faglia come strumento per la ricostruzione di eventi neotettonici, Memorie Società Geologica Italiana, 19, 621-626, 1978.

Brusdon, C., Mc Clatchey, J., and Unwin, D. J.: Spatial variations in the average rainfall-altitude relationship in Great Britain: an approach using geographically weighted regression, Int. J. Climatol., 21, 455-466, 2001.

Bull, W. B.: Tectonic geomorphology of mountains, a new approach to paleoseismology, Blackwell Publishing, Malden, USA, 316 pp., 2007.

Burdon, D. J.: Hydrogeology of some karstic areas of Greece. Actes de Colloque de Dubrovnik sur l'Hydrologie des roches calcaires fessures, A.I.H.S.-UNESCO, 73, 308-317, 1965.

Carroll, R. J. and Ruppert, D.: Transformation and Weighting in Regression, Chapman and Hall, New York, 1988.

Celico, P.: Idrogeologia dei massicci carbonatici, delle piane quaternarie e delle aree vulcaniche dell'Italia centromeridionale (Marche e Lazio meridionale, Abruzzo, Molise e Campania), Quaderni della Cassa per il Mezzogiorno, 4/2, 1-203, 1983.

Celico, P.: Prospezioni idrogeologiche, vol. 2, edited and published by: Liguori, E., Naples, Italy, p. 536, 1988.

Celico, F., Petrella, P. and Celico, P.: Hydrogeological behaviour of some fault zones in a carbonate aquifer of Southern Italy: an experimentally based model, Terra Nova, 18, 308-313, 2006.
Celico, F., Naclerio, G., Bucci, A., Nerone, V., Capuano, P., Carcione, M., Allocca, V., and Celico, P.: Influence of pyroclastic soil on epikarst formation: a test study in southern Italy, Terra Nova, 22, 110-115, 2010.

Civita, M., Olivero, G., Manzone, L., and Vigna, B.: Approcci sinergici nelle ricerche sui sistemi idrogeologici carbonatici del Piemonte meridionale. Atti Conv, Ricerca e Protezione delle Risorse Idriche Sotterranee delle Aree Montuose", 1, 53-86, 1992.

Darcy, H.: Les Fountaines Publiques de la Ville de Dijon, Victor Dalmont, Paris, 1-647, 1856.

Del Giudice, G., Padulano, R., and Rasulo, G.: Spatial prediction of the runoff coefficient in Southern Peninsular Italy for the index flood estimation, Hydrology Research, doi:10.2166/nh.2013.243, in press, 2013.

Delin, G. F., Healy, R. W., Lorenz, D. L., and Nimmo, J. R.: Comparison of local- to regional-scale estimates of ground-water recharge in Minnesota, USA, J. Hydrol., 334, 231-249, 2007.

De Vita, P., Agrello, D., and Ambrosino, F.: Landslide susceptibility assessment in ash-fall pyroclastic deposits surrounding SommaVesuvius: application of geophysical surveys for soil thickness mapping, J. Appl. Geophys., 59/2, 126-139, 2006.

De Vita, P., Allocca, V., Manna, F., and Fabbrocino, S.: Coupled decadal variability of the North Atlantic Oscillation, regional rainfall and karst spring discharges in the Campania region (southern Italy), Hydrol. Earth Syst. Sci., 16, 1389-1399, doi:10.5194/hess-16-1389-2012, 2012.

De Vita, P., Napolitano, E., Godt, J. W., and Baum, R. L.: Deterministic estimation of hydrological thresholds for shallow landslide initiation and slope stability models: case study from the Somma-Vesuvius area of southern Italy, Landslides, 10, 713728, doi:10.1007/s10346-012-0348-2, 2013.

Dripps, W. R. and Bradbury, K. R.: The spatial and temporal variability of groundwater recharge in a forested basin in northern Wisconsin, Hydrol. Process., 24, 383-392, 2010.

Drogue, C.: Coefficient d'infiltration ou infiltration eficace, sur le roches calcaires, Actes du Colloque d'Hydrologie en Pays Calcaire, Besancon, 15, 121-130, 1971.

Drogue, C.: Hydrodynamic of karstic aquifers: Experimental sites in the Mediterranea karst, Southern France, Inter. Contr. Hydrogeol. I.A.H., 13, 133-149, 1992.

European Commission: Directive 2000/60/EC of the European Parliament and of the Council of 23 October 2000 establishing a framework for community action in the field of water policy, Official Journal L327 of 22 December 2000, Bruxelles, 2000.

Fiorillo, F.: Tank-reservoir drainage as a simulation of the recession limb of karst spring hydrographs, Hydrogeol. J., 19, 1009-1019, 2011a.

Fiorillo, F.: The Role of the Evapotranspiration in the Aquifer Recharge Processes of Mediterranean Areas, in: "Evapotranspiration, From Measurements to Agricultural and Environmental Applications", edited by: Gerosa, G., InTech Publisher, Rijeka, Croatia, 373-388, 2011b.

Geiger, R.: Landolt-Börnstein - Zahlenwerte und Funktionen aus Physik, Chemie, Astronomie, Geophysik und Technik, alte Serie Vol. 3, in: Klassifikation der Klimate nach W. Köppen, Springer, Berlin, 603-607, 1954. 
Goldscheider, N.: A holistic approach to groundwater protection and ecosystem services in karst terrains, Aqua Mundi - Am, 06046, 117-124, 2012.

Goldscheider, N. and Drew, D.: Methods in karst hydrogeology, Taylor \& Francis, London, 1-264, 2007.

Goovaerts, P.: Geostatistical approaches for incorporating elevation into the spatial interpolation of rainfall, J. Hydrol., 228, 113-129, 2000.

Hartmann, A., Lange, J., Weiler, M., Arbel, Y., and Greenbaum, N.: A new approach to model the spatial and temporal variability of recharge to karst aquifers, Hydrol. Earth Syst. Sci., 16, 22192231, doi:10.5194/hess-16-2219-2012, 2012.

Hartmann, A., Weiler, M., Wagener, T., Lange, J., Kralik, M., Humer, F., Mizyed, N., Rimmer, A., Barberá, J. A., Andreo, B., Butscher, C., and Huggenberger, P.: Process-based karst modelling to relate hydrodynamic and hydrochemical characteristics to system properties, Hydrol. Earth Syst. Sci., 17, 3305-3321, doi:10.5194/hess-17-3305-2013, 2013.

Healy, R. W.: Estimating Groundwater Recharge, Cambridge University Press, 256 pp., 2010.

Henderson-Sellers, A. and Robinson, P. J.: Contemporary Climatology, John Wiley \& Sons, New York, 1986.

Horvat, B. and Rubinic, J.: Annual runoff estimation - an example of karstic aquifers in the transboundary region of Croatia and Slovenia, Hydrolog. Sci. J., 51, 314-324, 2006.

Houze, R. A.: Orographic effects on precipitating clouds, Rev. Geophys., 50, 1-47, 2012.

ISSKA: Swisskarst Project - toward a sustainable management of karst waters in Switzerland. Swiss Institute for Speleology and Karst studies, Swiss National Science Foundation, La Chaux-deFonds, Switzerland, p. 47, 2012.

Jeannin, P.-Y.: Structure et comportement hydraulique des aquifères karstiques, PhD thesis, University of Neuchâtel, Neuchâtel, p. 244, 1998.

Kessler, H.: Water balance investigation in the karstic region of Hungary, Actes de Colloque de Dubrovnik sur l'Hydrologie des roches calcaires fessures, A.I.H.S.-UNESCO, 73, 91-105, 1965.

Kiraly, L.: Rapport sur l'état actuel des connaissances dans le domaines des caractères physiques des roches karstiques, edited by: Burger, A. and Dubertret, L., Hydrogeology of karstic terrains, Int. Union of Geol. Sci. B, 3, 53-67, 1975.

Kiraly, L.: Karstification and Groundwater Flow, in: Evolution of karst: from prekarst to cessation, Postojna-Ljubljana, edited by: Gabrovsek, F., Zalozba ZRC, Ljubljana, Slovenia, 155-190, 2002.

Klimchouk, A. B.: The formation of Epikarst and its role in Vadose Speleogenesis, in: Speleogenesis, Evolution of Karst Aquifers, edited by: Klimchouk, A. B., Ford, D. C., Palmer, A. N., and Dreybrodt, W., Nat. Speleol. Soc., Huntsville, 91-99, 2000.

Lerner, D. N., Issar, A. S., and Simmers, I.: Groundwater recharge, a guide to understanding and estimating natural recharge, Rep. 8, International Association of Hydrogeologists, Kenilworth, p. 354, 1990.

Mangin, A.: Contribution à l'étude hydrodynamique des aquifères karstiques, Ann. Spéléol., 29, 283-332; 29, 495-601, 30, 21124,1975
Marquínez, J., Lastra, J., and García, P.: Estimation models for precipitation in mountainous regions: the use of GIS and multivariate analysis, J. Hydrol., 270, 1-11, 2003.

Naclerio, G., Petrella, E., Nerone, V., Allocca, V., De Vita, P., and Celico, F.: Influence of topsoil of pyroclastic origin on microbial contamination of groundwater in fractured carbonate aquifers, Hydrogeol. J., 16, 1057-1064, 2008.

Naclerio, G., Nerone, V., Bucci, A., Allocca, V., and Celico, F.: Role of organic matter and clay fraction on migration of Escherichia Coli cells through pyroclastic soils, southern Italy, Colloids Surf. B, 72, 57-61, 2009.

Parajka, J. and Szolgay, J.: Grid-based mapping of long-term mean annual potential and actual evapotranspiration in Slovakia, IAHS Publ., Proceedings of the HeadWater'98 Conference, April 1998, Merano, Italy, 123-129, 1998.

Patacca, E. and Scandone, P.: Geology of the Southern Apennines, Ital. J. Geosci., 7, 75-119, 2007.

Ravbar, N., Engelhardt, I., and Goldscheider, N.: Anomalous behaviour of specific electrical conductivity at a karst spring induced by variable catchment boundaries: the case of the Podstenjsek spring, Slovenia, Hydrol. Process., 25, 2130-2140, 2011.

Roe, G. H.: Orographic precipitation, Annu. Rev. Earth Planet. Sci., 33, 645-671, 2005.

Santoro, M.: Sulla applicabilità della formula di Turc per il calcolo della evapotraspirazione effettiva in Sicilia, Proceedings I International Conference on Groundwater, I.A.H., Palermo, 1970.

Scanlon, B. R., Healy, R. W., and Cook, P. G.: Choosing appropriate techniques for quantifying groundwater recharge, Hydrogeol. J., 10, 18-39, 2002.

Scanlon, B. R., Keese, K. E., Flint, A. L., Flint, L. E., Gaye, C. B., Edmunds, W. M., and Simmers, I.: Global synthesis of groundwater recharge in semiarid and arid regions, Hydrol. Process., 20, 3335-3370, 2006.

Sodeman, P. C. and Tysinger, J. E.: Effect of forest cover upon hydrologic characteristics of a small watershed in limestone region of East Tennesse, Actes de Colloque de Dubrovnik sur l'Hydrologie des roches calcaires fessures, A.I.H.S.-UNESCO, 73, 135-151, 1965.

Soulios, G.: Infiltration efficace dans le karst hellenique, J. Hydrol., 75, 343-356, 1984

Stephens, D. B.: Vadose Zone Hydrology, CRC Press, Boca Raton, Florida, USA, 339 pp., 1995.

Turc, L.: Le bilan d'eau des sols: relations entre les précipitations, l'évaporation et l'éecolument, Annales Agronomiques, 5, 491$595,1954$.

Vilimonovic, J.: A contribution of the study of groundwater intake recharge in karst, Actes de Colloque de Dubrovnik sur l'Hydrologie des roches calcaires fessures, A.I.H.S.-UNESCO, 73, 482-499, 1965.

Vuglinski, V. S.: Methods for the study of laws for the distribution of precipitation in mediu-high mountains (illustrated by the Vitim River Basin), Distribution of precipitation in Mountainous Areas, WMO Publ., 326, 212-221, 1972.

White, W. B.: Conceptual models for carbonate aquifer, Ground Water, 7, 15-21, 1969.

White, W. B.: Karst hydrology: recent developments and open questions, Eng. Geol., 65, 85-105, 2002. 